\title{
Reuse of Treated Municipal Wastewater under Different Growing Seasons for the Spinach Production
}

\author{
Majida Mcheik ${ }^{1,2,3}$, Joumana Toufaily ${ }^{1,2}$, Mariam Akil1,2, Tayssir Hamieh ${ }^{1,2}$, \\ Marie Therese Abi Saab ${ }^{4}$, Bachar Haj Hassan², Youssef Rouphael ${ }^{5}$
}

${ }^{1}$ Laboratory of Materials, Catalysis, Environment and Analytical Methods Labortory (MCEMA), Ecole Doctorale des Sciences et de Technologies (EDST), FS (Science Faculty), Lebanese University, Hadath, Lebanon

${ }^{2}$ Laboratoire des Etudes Appliquées au Développement Durable et Energie Renouvelable (LEADDER), PRASE, EDST, Université Libanaise, Hadath, Liban

${ }^{3}$ Ministry of Agriculture, Bir Hassan, Lebanon

${ }^{4}$ Lebanese Agricultural Research Institute, Fanar, Lebanon

${ }^{5}$ University of Naples, Naples, Italy

Email: *joumana.toufaily@ul.edu.lb, ma_mcheik@yahoo.com, tayssir.hamieh@ul.edu.lb

How to cite this paper: Mcheik, M., Toufaily, J., Akil, M., Hamieh, T., Saab, M.T.A., Hassan, B.H. and Rouphael, Y. (2018) Reuse of Treated Municipal Wastewater under Different Growing Seasons for the Spinach Production. American Journal of Analytical Chemistry, 9, 482-499.

https://doi.org/10.4236/ajac.2018.910036

Received: August 21, 2018

Accepted: October 21, 2018

Published: October 24, 2018

Copyright $\odot 2018$ by authors and Scientific Research Publishing Inc. This work is licensed under the Creative Commons Attribution International License (CC BY 4.0).

http://creativecommons.org/licenses/by/4.0/

\begin{abstract}
A study was conducted in the Bekaa valley of Lebanon aiming to produce spinach leaves with treated effluent from Joub Janine plant under two growing seasons. Two experiments were laid out in a randomized complete block design. The effect of water quality on the qualitative, quantitative aspects and microbiological contamination of leaves was assessed. The results showed that the treated wastewater from Joub Janine plant was of category III. The highest mean marketable yields was recorded for T7 $\left(4727 \mathrm{~g} \cdot \mathrm{m}^{-2}\right)$ followed by T6 $\left(3533 \mathrm{~g} \cdot \mathrm{m}^{-2}\right)$ that were drip irrigated with treated wastewater. The uptake of $\mathrm{K}, \mathrm{Mg}, \mathrm{Na}$ and $\mathrm{Cl}$ was significantly $49.09 \%, 30.20 \%, 96.79 \%$ and $33.20 \%$, respectively, higher in the spring than in autumn. The nitrate levels in all treatments and seasons were below the maximum level in foodstuffs as provided by the European Commission regulations. For the lipophilic fraction, there was no significant difference among treatments and also among treatments and seasons interacting together and the highest hydrophilic fraction and total phenols levels recorded for the autumn rather than the summer season. In general, pathogenic bacteria was absent on spinach leaves for all treatments and growing seasons.
\end{abstract}

\section{Keywords}

Treated Wastewater, Spinach Cultivation, Mineral Composition, Qualitative Parameters 


\section{Introduction}

Water scarcity poses serious economic, social and even political concerns in all of its aspects. Many irrigated areas around the world are experiencing water shortages due to severe factors, such as climate change and ground water pollution [1].

Most of the water consumption in many countries is allocated to agricultural practices, which consume $66 \%$ of the available water [2].

Countries suffering from water shortages are forced to use non-conventional resources, mainly water harvesting and treated wastewater. Under these circumstances, treated wastewater use can help to mitigate the damaging effects of local water deficits but under controlled conditions to minimize hazards from pathogenic and toxic contaminants of the agricultural products, soils, surface, and ground water [3].

In Lebanon, like in many other Mediterranean countries, demands on water resources for households, commercial, industrial, and agricultural use are on the increase due to rapid population growth and demographic shifts [4] [5]. In this context, the lack of sufficient resources makes the use of wastewater a necessity particularly for agricultural purposes, and hence become an economically attractive proposition [6] [7]. However, there is still little knowledge about the harmful effects on human health and the environment.

Harmful effects are mainly due to associated pathogens and other undesirable constituents depending on the source [8] [9]. According to the proposed Lebanese guidelines, it is strictly forbidden to grow vegetables to be eaten raw; however, cooked vegetables are allowed to be grown with an effluent classified as "category I" [10].

Spinach leaves are currently cultivated and consumed as part of a main course or side dish in Lebanon, The Bekaa valley is one of the main farming areas of spinach currently being irrigated with non-conventional water resources due to the prevailing water scarcity in the plain. Harvested leaves are transported to markets in urban areas. According to the recent census conducted by the Ministry of Agriculture and the Food and Agriculture Organization of the United Nations, the cultivated area of spinach in Lebanon is around 342.1 hectares giving a total production of 3665.9 tons [11]. Spinach is available throughout the year, although its primary season runs from about early spring in March through May, then summer season and again in the fall from September through October.

The reuse of treated wastewater for crop production largely depends on adopting appropriate measures aiming at optimizing crop yields and quality, maintaining soil productivity and safeguarding the environment. Therefore, the aim of the current work was to assess the production of spinach leaves, in two growing seasons (summer and fall) with treated municipal wastewater in order to study the impact on yield, mineral composition, qualitative parameters and microbial contamination. 


\section{Materials and Methods}

\subsection{Experimental Site and Climate}

The experiment was carried out during two consecutive growing seasons in 2016 at the experimental field of the Litani River Authority (LRA) agricultural extension center in Khirbet Kanafar village (Lebanon, $33.63^{\circ} \mathrm{N}$ lat, $35.77^{\circ} \mathrm{E}$ long, 859 $\mathrm{m}$ above sea level) (Figure 1). Spinach was cultivated in summer season from 20 August 2016 to 6 October 2016, and in autumn season from 14 October 2016 to 8 December 2016. The treated effluent of the Wastewater Treatment Plant (WWTP) that is serving the nearby village of Joub Janine and located very close to the LRA was used in the experiment. The WWTP provides a secondary treatment. It has a maximum capacity of $10,000 \mathrm{~m}^{3}$ per day and currently receives $7000-8000 \mathrm{~m}^{3}$ per day during the summer time. It is connected to the LRA and serves part of the irrigated land belonging to the station.

The climate of the area is typically Mediterranean, characterized by a hot and dry season from April to October. The main weather parameters were obtained from a standard agro-meteorological station located at the experimental station of the LRA that is very close to the field trial. The weather regimes, in terms of reference evapotranspiration (ETo), precipitation $(\mathrm{P})$, maximum temperature (Tmax), minimum temperature (Tmin) and mean relative humidity (RHmean) during the season 2016 are given in Figure 2.

In general, the average maximum air temperature was $30.4^{\circ} \mathrm{C}$ from 20 August 2016 to 6 October 2016 and $20.7^{\circ} \mathrm{C}$ from 14 October 2016 to 8 December 2016, whereas the average minimum air temperature was $14.3^{\circ} \mathrm{C}$ during $\mathrm{Au}$ gust-October and $7.0^{\circ} \mathrm{C}$ during Mid October-Mid December. Total rain was 0.6 $\mathrm{mm}$ and $201 \mathrm{~mm}$ during the summer and autumn growing season, respectively.

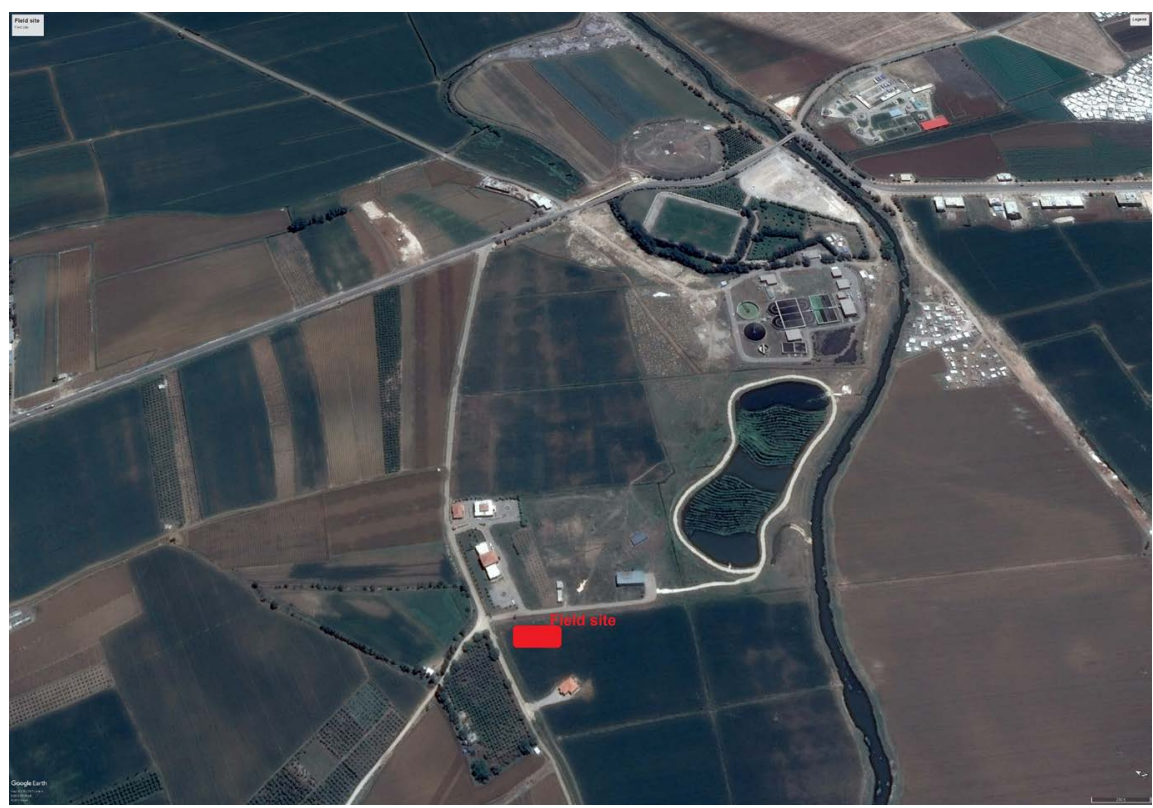

Figure 1. Satellite imagery of study site in Joub Janine region. 


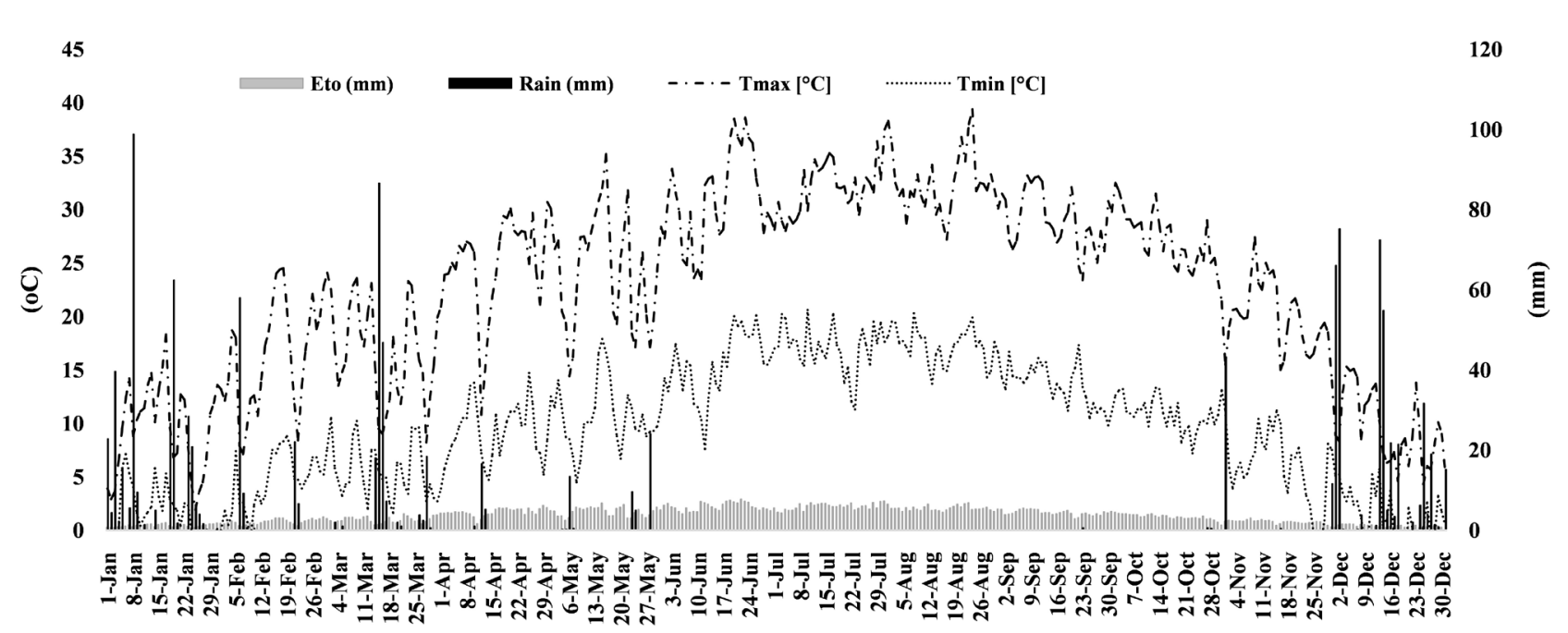

Figure 2. Daily climate data for the year 2016 as recorded for Joub Janine region.

The soil of the study area is sandy clay loam (USDA textural soil classification) with $53 \%$ Clay, $31 \%$ clay and $15 \%$ silt. Field slope was less than $0.1 \%$ and total available water holding capacity within the top $1 \mathrm{~m}$ of soil profile was 109 $\mathrm{mm}$.

\subsection{Experimental Design, Treatments and Agronomic Management}

The experiment was laid out with eight treatments: T1: Faten variety sprinkler irrigated with fresh water (FW-S-V1); T2: Fayez variety sprinkler irrigated with fresh water (FW-S-V2); T3: Faten variety drip irrigated with fresh water (FW-D-V1); T4: Fayez variety drip irrigated with fresh water (FW-D-V2); T5: Faten variety sprinkler irrigated with treated water (TW-S-V1); T6: Fayez variety sprinkler irrigated with treated water (TW-S-V2); T7: Faten variety drip irrigated with treated water (TW-D-V1); T8: Fayez variety drip irrigated with treated water (TW-D-V2); . Treatments were organized in a randomized complete block design with three replicates. Each experimental unit consisted of a 9 $\mathrm{m}^{2}$ plot. The plants in both seasons were placed with $25 \mathrm{~cm}$ between the rows and $15 \mathrm{~cm}$ within the row living a plant density of 27 plants $\mathrm{m}^{-2}$.

The plots under drip irrigation were equipped with low polyethylene surface laterals. All the laterals were supplied with in-line drippers (theoretical discharge rate of $\left.4 \mathrm{~L} \cdot \mathrm{h}^{-1}\right)$; each lateral fed one row of plants. The plots under sprinkler irrigation were equipped with minisprayers having a discharge of $0.26 \mathrm{~m}^{3} / \mathrm{hr}$ and placed on the middle of plot. The experiment was equipped with separate reservoirs and head units for the treatments irrigated with fresh water and those irrigated with treated effluent. Filters were manually cleaned.

\subsection{Soil and Water Sampling and Analysis}

Soil samples were taken at the beginning and at the end of each growing season at two different depths: $0-20 \mathrm{~cm}$ and $20-40 \mathrm{~cm}$. The samples were analyzed for 
physical chemical properties, the presence of micronutrients and trace elements.

Concerning irrigation water, the main physic-chemical, microbial characteristics and trace metals content of both kinds of water (F and TW) were monitored. Standard methods were used in the laboratory to measure the biochemical oxygen demand (BOD5) [12], the total dissolved salts (TDS), electrical conductivity (EC), the $\mathrm{pH}$, etc. The microbiological analysis of Total coliforms (TC), Faecal coliforms (FC), Escherichia coli (E. coli) and salmonella was done according to standard methods) [10].

\subsection{Production and Microbial Contamination of Spinach}

At the end of both experiments the marketable fresh yield expressing per square meter as well as the percentage of dry matter were recorded.

In addition, spinach leaves (500) were harvested from each experimental unit in order to measure microbial contamination, mainly the Enterobacteriacae, Staphylococcus aureus, Clostridium perfringens, L. monocytogenes, Faecal coliforms, E. coli and Salmonella. In the laboratory, $100 \mathrm{~g}$ of leaves were homogenized with $900 \mathrm{~mL}$ of sterile water by a stomacher. Then, ten-fold dilutions were made within the same medium. Faecal coliform and E. coli were measured using membrane filtration techniques [12]. The Salmonella detection was done acording to the method of [13].

\subsection{Mineral Analysis}

Dried spinach leaf tissues were ground in a Wiley Mill to pass through an 841 microns screen, and then portions of the dried tissues were used for mineral analysis. Total $\mathrm{N}$ concentration in fruit tissue was determined by Kjeldahl method following mineralization with sulphuric acid in the presence of potassium sulfate and low concentration of copper catalyst [14].

For the $\mathrm{NO}_{3}, \mathrm{P}, \mathrm{S}, \mathrm{K}, \mathrm{Ca}, \mathrm{Mg}$ and $\mathrm{Na}$ analysis, $250 \mathrm{mg}$ of finely ground dried plant tissues (leaf and fruit) were suspended in $50 \mathrm{ml}$ of ultrapure water (Milli-Q, Merck Millipore, Darmstadt, Germany) and subjected to four freeze-thaw cycles in liquid nitrogen followed by shaking water bath (ShakeTemp SW22, Julabo, Seelbach, Germany) at $80^{\circ} \mathrm{C}$ for $10 \mathrm{~min}$. The mixture was centrifuged at $6000 \mathrm{rpm}$ for $10 \mathrm{~min}$ (R-10M, Remi Elektrotechnik Limited, India), then filtered through a $0.20 \mu \mathrm{m}$ filter paper (Whatman International Ltd., Maidstone, U.K.), as described previously by [15], Potassium, $\mathrm{Ca}, \mathrm{Mg}$ and $\mathrm{Na}$ were separated by ion chromatography (ICS-3000, Dionex, and Sunnyvale, CA, USA) and quantified through an electrical conductivity detector. Chromatographic separation was achieved in isocratic mode on an IonPac CS12A analytical column $(4 \times 250$ $\mathrm{mm}$, Dionex, Corporation) equipped with an IonPac CG12A precolumn $(4 \times$ $250 \mathrm{~mm}$, Dionex, Corporation) and a self-regenerating suppressor CERS500 (4 $\mathrm{mm}$, Dionex, Corporation). The nitrate, $\mathrm{P}$ and $\mathrm{S}$ contents were also measured through ion chromatography coupled to a conductivity detector. A IonPac ATC-HC anion trap $(9 \times 75 \mathrm{~mm})$, and a AS11-HC analytical column $(4 \times 250$ 
$\mathrm{mm})$ equipped with an AG11-HC precolumn $(4 \times 50 \mathrm{~mm})$ and a self-regenerating suppressor AERS500 (4 mm) were used for separation.

\subsection{Leaf Quality Assessment}

The hydrophilic fraction (HAA) from freeze-dried spinach leaves $(200 \mathrm{mg}$ ) was extracted with distilled water and its antioxidant activity was measured with the N,N-dimethyl-p-phenylenediamine (DMPD) method [16]. The lipophilic fraction (LAA) was also extracted from freeze-dried fruits $(200 \mathrm{mg})$ with methanol, and antioxidant activity of this extract was measured with the 2,2'-azinobis 3-ethylbenzothiazoline-6-sulfonic acid ABTS method [17]. The hydrophilic and lipophilic antioxidant activities were determined by UV-Vis spectrophotometry. The absorbance of the solutions was measured at 505 and $734 \mathrm{~nm}$, respectively. HAA and LAA were expressed as mmol ascorbic acid and as mmol of Trolox (6-hydroxy-2,5,7,8-tetramethylchroman-2-carboxylic acid) per $100 \mathrm{~g}$ of dry weight, respectively.

The total phenolic content in methanolic extracts was determined using the Folin-Ciocalteau procedure [18] with gallic acid as a standard. A $100 \mu \mathrm{l}$ aliquot of the supernatant was combined with $500 \mu \mathrm{l}$ of Folin-Ciocalteau's reagent (Sigma Aldrich Inc, St Louis, MO, USA) and $400 \mu \mathrm{l}$ of $7.5 \%$ sodium carbonate/water $(\mathrm{w} / \mathrm{v})$. Absorption was measured after $30 \mathrm{~min}$ at $765 \mathrm{~nm}$ using a UV-Vis spectrophotometer, and the result was expressed as mg gallic acid (Sigma Aldrich Inc, St Louis, MO, USA) per $100 \mathrm{~g}$ dry weight.

\subsection{Statistical Analysis}

Analysis of variance (ANOVA) of the experimental data was performed using SPSS 10 for Windows, 2001 (SPSS Inc., USA). To separate treatment means within each measured parameter, Duncan's multiple-range test was performed at $\mathrm{P} \leq 0.05$. Combined analysis of variance over two growing seasons was performed for crop growth parameters, mineral composition, leaf quality parameters, heavy metals and bacterial contamination.

\section{Results and Discussions}

\subsection{Water Quality}

Table 1 reports the physico-chemical parameters, microbial characteristics and trace metals of the fresh and the treated water analysed during the trial.

The level of TSS ( $52 \mathrm{mg} \cdot \mathrm{L}^{-1}$ ) in wastewater is within the level proposed by the environmental limit values decision of MOE for surface water [19] as well as for the proposed Lebanese guidelines for wastewater reuse in irrigation [20]. The levels of COD $\left(210 \mathrm{mg} \cdot \mathrm{L}^{-1}\right)$ and BOD5 $\left(45 \mathrm{mg} \cdot \mathrm{L}^{-1}\right)$ in treated wastewater were higher than the admissible limits of water category I, however, those parameters in freshwater were within the admissible limits. The levels of nitrates and phosphates were low in both fresh and wastewater. The Total coliforms were highly present in both fresh and wastewater while the Feacal coliforms $\left(3.5 \times 10^{\wedge} 3\right.$ 
$\mathrm{CFU} / 100 \mathrm{~mL}$ ) were present in treated water and they were exceeding the proposed limit value. Furthermore, the Salmonella was detected in treated water however in fresh water it was completely absent. [21] observed that pathogens can enter plants and become internalized. Other studies showed that E. coli could be transported into the edible part of lettuce from soil through root system, and Salmonella could be transported from contaminated roots to the aerial parts of lettuce seedlings [22].

Overall, the water treated in Joub Janine plant is of category III as proposed by the Lebanese guidelines and it could easily reach category I if well treated.

Table 1. Fresh water and treated effluent average quality and limit values for the reuse of TWW in Lebanon.

\begin{tabular}{|c|c|c|c|c|c|c|}
\hline & \multirow[b]{2}{*}{ FW } & \multirow[b]{2}{*}{ TW } & \multirow[t]{2}{*}{$\begin{array}{c}\text { Environmental limit } \\
\text { values for surface water } \\
\text { based on MoE Decision } \\
8 / 1(\mathrm{MoE}, 2001)\end{array}$} & \multicolumn{3}{|c|}{$\begin{array}{l}\text { Effluent specifications for wastewater } \\
\text { reuse in irrigation based on proposed } \\
\text { Lebanese guidelines (FAO, 2011) }\end{array}$} \\
\hline & & & & $\begin{array}{c}\text { Water } \\
\text { Category I }\end{array}$ & $\begin{array}{c}\text { Water } \\
\text { Category II }\end{array}$ & $\begin{array}{c}\text { Water } \\
\text { Category III }\end{array}$ \\
\hline \multicolumn{7}{|l|}{$\begin{array}{l}\text { Physico-chemical } \\
\text { parameters }\left(\mathrm{mg} \cdot \mathrm{L}^{-1}\right)\end{array}$} \\
\hline $\mathrm{pH}$ & 7.85 & 7.82 & $6-9$ & $6-9$ & $6-9$ & $6-9$ \\
\hline COD & 90.50 & 210.00 & 125 & 125 & 250 & 250 \\
\hline BOD5 & 14.00 & 45.00 & 25 & 25 & 100 & 100 \\
\hline Total Suspended Solids & 5.32 & 52.00 & 60 & 60 & 200 & 200 \\
\hline Nitrates & 9.30 & 3.00 & 90 & 30 & 30 & 30 \\
\hline Phosphates & 0.06 & 0.50 & 5 & - & - & - \\
\hline Potassium & 4.50 & 9.60 & - & - & - & - \\
\hline \multicolumn{7}{|l|}{ Pathogens in water } \\
\hline Total Coliform (CFU/100mL) & $2.6 \times 10^{\wedge} 2$ & $6.16 \times 10^{\wedge} 4$ & - & - & - & - \\
\hline Fecal Coliform (CFU/100mL) & & $3.5 \times 10^{\wedge} 3$ & $<2000$ & $<200$ & $<1000$ & - \\
\hline E. coli $(\mathrm{CFU} / 100 \mathrm{~mL})$ & & $7.5 \times 10^{\wedge} 2$ & $<2000$ & $<200$ & $<1000$ & - \\
\hline Salmonella & Absent & Present & Absent & Absent & Absent & Absent \\
\hline \multicolumn{7}{|l|}{ Trace metals $\left(\mathrm{mg} \cdot \mathrm{L}^{-1}\right)$} \\
\hline $\mathrm{Zn}$ & 789.47 & 789.47 & 5 & & & \\
\hline $\mathrm{Cu}$ & $<0.001$ & $<0.001$ & 0.5 & & & \\
\hline $\mathrm{Pb}$ & 444.44 & 444.44 & 0.5 & & & \\
\hline Mn & 0.23 & 0.52 & 1 & & & \\
\hline $\mathrm{Ni}$ & 372.09 & 3651.16 & 0.5 & & & \\
\hline $\mathrm{Hg}$ & 0.0100 & 0.0003 & 0.05 & & & \\
\hline As & $<0.001$ & $<0.001$ & 0.1 & & & \\
\hline $\mathrm{Cd}$ & 111.1100 & $<0.001$ & 0.2 & & & \\
\hline $\mathrm{Cr}$ & $<0.001$ & $<0.001$ & 2 & & & \\
\hline
\end{tabular}




\subsection{Marketable Yield and Dry Matter Percentage}

The analysis of variance and mean comparisons for marketable yield and dry matter percentage of spinach plants grown under different water quality regimes, irrigation methods and growing seasons were reported in Figure 3 and Figure 4.
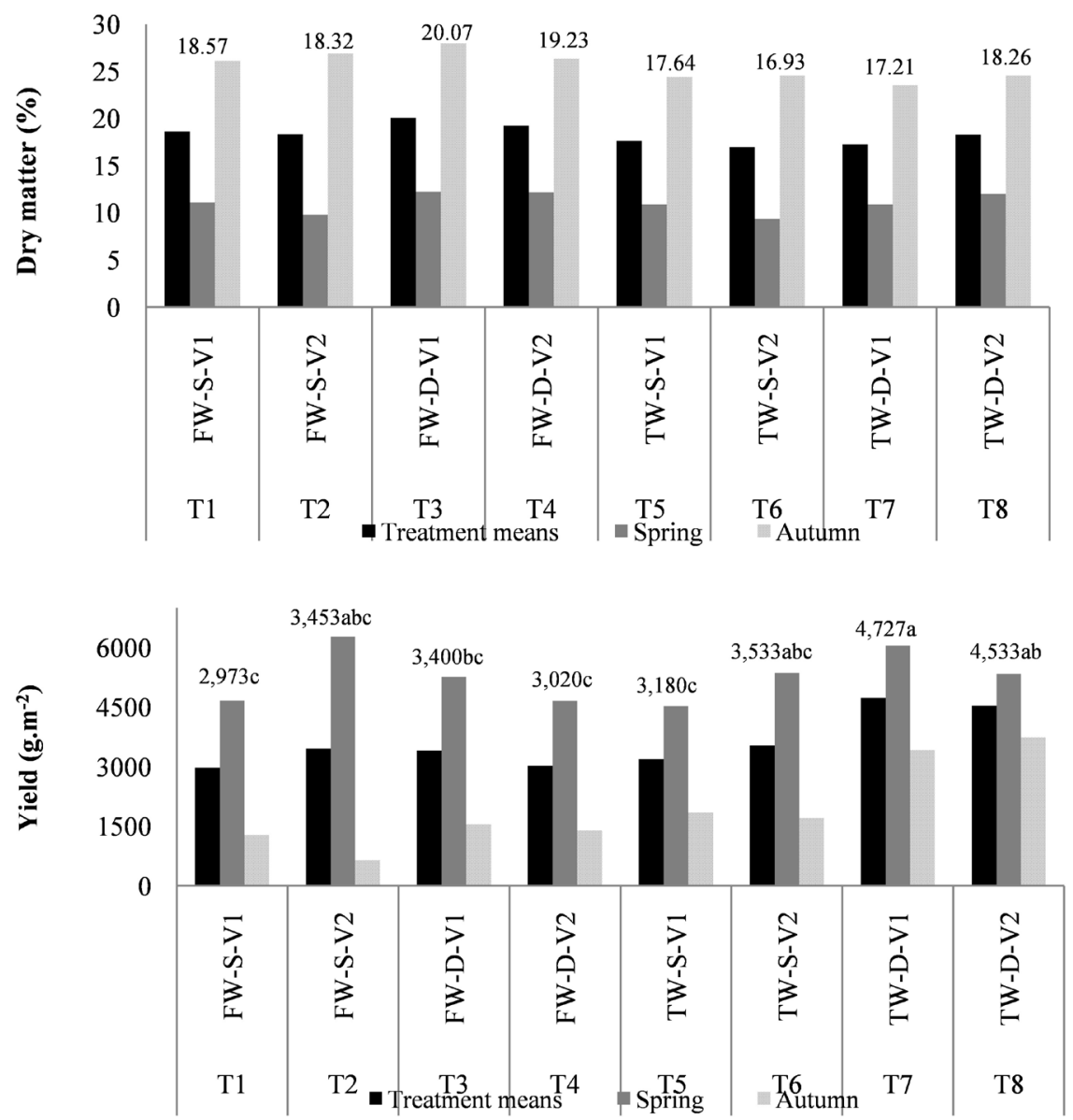

Figure 3. Analysis of variance and mean comparisons for marketable yield and dry matter percentage of spinach plants grown under different water quality regimes, irrigation methods and growing seasons.

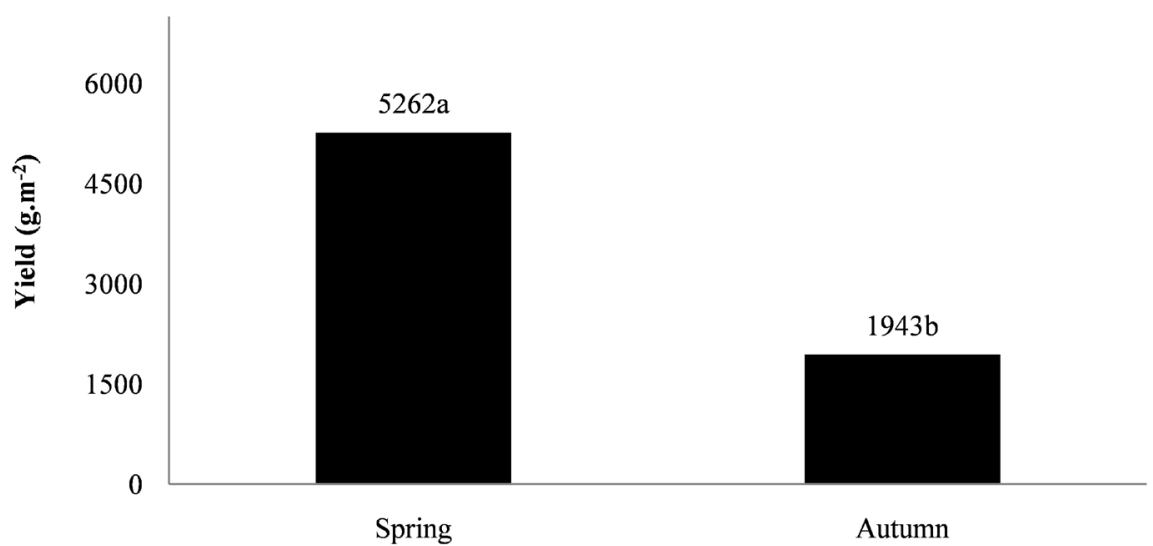




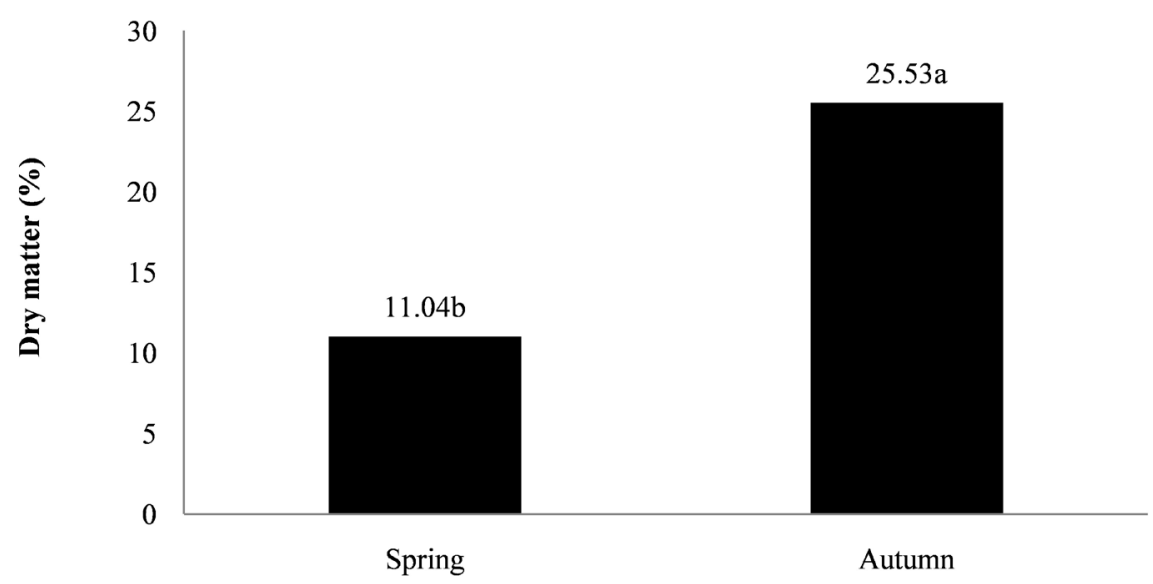

Figure 4. Seasonal means for marketable yield and dry matter percentage of spinach plants grown under different water quality regimes, irrigation methods and growing seasons.

For the marketable yield, considering the treatment as the source of variance, there was a significant difference among the different treatments (Figure 3), with the highest mean marketable yields recorded for T7 $\left(4727 \mathrm{~g} \cdot \mathrm{m}^{-2}\right)$ followed by T6 $\left(3533 \mathrm{~g} \cdot \mathrm{m}^{-2}\right)$ that were drip irrigated with treated wastewater. The treatments that were drip irrigated with fresh water gave respectively lower yields with $3400 \mathrm{~g} \cdot \mathrm{m}^{-2}$ for $\mathrm{T} 3$ and $3020 \mathrm{~g} \cdot \mathrm{m}^{-2}$ for T4. In addition, under drip irrigation, spinach variety Faten (V1) showed $12.5 \%$ and $4 \%$ higher yield than variety Fayez (V2) under fresh water and wastewater, respectively. On the contrary, under sprinkler irrigation, spinach V2 showed a better performance than V1 with $16 \%$ and $11 \%$ higher yields under fresh water and wastewater, respectively. However, the treatments means showed close values under sprinkler irrigation independently of the quality of irrigation water.

Considering the season as the source of variance, there was a significant difference, among both growing seasons with the highest seasonal mean for the summer $\left(5262 \mathrm{~g} \cdot \mathrm{m}^{-2}\right)$ while the mean in autumn was $1943 \mathrm{~g} \cdot \mathrm{m}^{-2}$ (Figure 4). The lowest marketable yield recorded in autumn than in summer growing season could be attributed to the reduced evaporative demand of the environment such as lower global radiation and air temperature. In addition, the uptake of available nutrients existing in the soil and in irrigation waters of different qualities could also explain the fluctuations between seasons and among treatments. The present results are in agreement with the findings of [23] who found variation in spinach yield among different growing seasons. Moreover, in a similar study [24] indicated higher crop production under treated wastewater. Probably, treated wastewater provides part of the nutrient amount necessary during the crop cycle, as emphasized by [25] and [26].

For the percentage dry matter, considering the treatment as the source of variance, there was no significant difference among the different treatments (Figure 4). Considering the season as the source of variance, there was a significant difference, among the seasons with the highest seasonal mean for the au- 
tumn (25.5\%) while the mean in the summer was $11.0 \%$ (Figure 4 ).

\subsection{Leaf Mineral Composition of Spinach Plants}

The leaf mineral composition ( $\mathrm{N}, \mathrm{PO}_{4}, \mathrm{~K}, \mathrm{Ca}, \mathrm{Mg}, \mathrm{Na}$ and $\mathrm{Cl}$ ) were significantly influenced by the treatment $(\mathrm{T})$, season $(\mathrm{S})$ and the interaction of $\mathrm{T} \times \mathrm{S}$ for most nutrients (Table 2).

Table 2. Analysis of variance and mean comparisons for leaf mineral composition of spinach plants grown under water quality regimes, irrigation methods and growing seasons.

\begin{tabular}{|c|c|c|c|c|c|c|c|c|c|c|c|c|}
\hline \multirow{2}{*}{ Source of variance } & $\mathrm{N}$ & \multicolumn{2}{|c|}{$\mathrm{PO} 4$} & \multicolumn{2}{|l|}{$\mathrm{K}$} & \multicolumn{2}{|c|}{$\mathrm{Ca}$} & \multicolumn{2}{|c|}{$\mathrm{Mg}$} & \multicolumn{2}{|c|}{$\mathrm{Na}$} & \\
\hline & (g. $\mathrm{kg}^{-1}$ d.wt.) & \multicolumn{2}{|c|}{ (g. $\mathrm{kg}^{-1}$ d.wt.) } & \multicolumn{2}{|c|}{ (g. $\mathrm{kg}^{-1}$ d.wt.) } & \multicolumn{2}{|c|}{ (g.kg ${ }^{-1}$ d.wt.) } & \multicolumn{2}{|c|}{ (g.kg ${ }^{-1}$ d.wt.) } & \multicolumn{2}{|c|}{ (g. $\mathrm{kg}^{-1}$ d.wt.) } & $(\mathrm{g} \cdot \mathrm{kg}$ \\
\hline Treatment $(\mathrm{T})$ & ns & * & & * & & $* * *$ & & $* * *$ & & $* * *$ & & ns \\
\hline Season (S) & $* * *$ & * & & $* * *$ & & ns & & $* * *$ & & $* * *$ & & $* * *$ \\
\hline $\mathrm{T} \times \mathrm{S}$ & ns & $* * *$ & & $* * *$ & & $* *$ & & * & & * & & $* *$ \\
\hline \multicolumn{13}{|l|}{ Treatment } \\
\hline $\mathrm{T} 1$ & 39.60 & 6.21 & a & 52.41 & $\mathrm{a}$ & 0.72 & a & 9.39 & $a b$ & 9.15 & $\mathrm{~b}$ & 8.64 \\
\hline $\mathrm{T} 2$ & 40.71 & 6.80 & $\mathrm{a}$ & 51.63 & $\mathrm{a}$ & 0.34 & $\mathrm{bc}$ & 10.84 & $\mathrm{a}$ & 15.03 & $\mathrm{a}$ & 10.58 \\
\hline T3 & 36.90 & 6.46 & $\mathrm{a}$ & 52.23 & a & 0.40 & $\mathrm{bc}$ & 9.87 & $a b$ & 9.92 & $\mathrm{~b}$ & 9.77 \\
\hline $\mathrm{T} 4$ & 37.19 & 6.60 & $\mathrm{a}$ & 49.15 & $\mathrm{a}$ & 0.55 & $a b$ & 10.44 & $\mathrm{a}$ & 6.38 & c & 9.38 \\
\hline T5 & 39.89 & 5.80 & $\mathrm{ab}$ & 49.56 & $\mathrm{a}$ & 0.28 & c & 9.85 & $a b$ & 9.51 & $\mathrm{~b}$ & 8.51 \\
\hline T6 & 40.10 & 4.17 & $\mathrm{~b}$ & 39.80 & $\mathrm{~b}$ & 0.24 & c & 8.65 & $\mathrm{~b}$ & 10.98 & $\mathrm{~b}$ & 8.00 \\
\hline T7 & 41.06 & 5.30 & $\mathrm{ab}$ & 43.39 & $\mathrm{ab}$ & 0.34 & $\mathrm{bc}$ & 6.48 & c & 6.28 & c & 10.95 \\
\hline T8 & 41.56 & 6.47 & a & 46.50 & $\mathrm{ab}$ & 0.26 & c & 6.89 & $c$ & 6.06 & $c$ & 9.59 \\
\hline
\end{tabular}

Season

$\begin{array}{lllllllllllll}\text { Autumn } & 44.40 \mathrm{a} & 6.37 & \mathrm{a} & 37.99 & \mathrm{~b} & 0.43 & 7.76 & \mathrm{~b} & 5.92 & \mathrm{~b} & 8.01 & \mathrm{~B} \\ \text { Summer } & 35.50 \mathrm{~b} & 5.65 & \mathrm{~b} & 56.94 & \mathrm{a} & 0.36 & 10.09 & \mathrm{a} & 11.65 & \mathrm{a} & 10.67 & \mathrm{~A}\end{array}$

$\mathrm{T} \times \mathrm{S}$

$\begin{array}{lccccccccccccc}\text { T1 Autumn } & 44.33 & 7.90 & \mathrm{abc} & 50.02 & \mathrm{abcd} & 1.04 & \mathrm{a} & 9.10 & \mathrm{ab} & 6.39 & \text { efgh } & 8.77 & \mathrm{Bc} \\ \text { T1 Summer } & 34.88 & 4.52 & \text { ef } & 54.80 & \mathrm{abc} & 0.40 & \mathrm{bc} & 9.68 & \mathrm{ab} & 11.92 & \mathrm{~b} & 8.50 & \mathrm{Bc} \\ \text { T2 Autumn } & 49.74 & 9.87 & \mathrm{a} & 49.84 & \mathrm{abcd} & 0.29 & \mathrm{c} & 10.11 & \mathrm{ab} & 10.32 & \mathrm{bcde} & 10.09 & \mathrm{Bc} \\ \text { T2 Summer } & 34.69 & 4.75 & \mathrm{def} & 52.83 & \mathrm{abc} & 0.37 & \mathrm{bc} & 11.33 & \mathrm{a} & 18.16 & \mathrm{a} & 10.91 & \mathrm{Bc} \\ \text { T3 Autumn } & 45.03 & 6.68 & \mathrm{bcde} & 43.55 & \mathrm{cde} & 0.29 & \mathrm{c} & 8.34 & \mathrm{~b} & 7.65 & \mathrm{bcdefgh} & 8.32 & \mathrm{Bc} \\ \text { T3 Summer } & 31.48 & 6.31 & \mathrm{bcde} & 58.01 & \mathrm{ab} & 0.47 & \mathrm{bc} & 10.89 & \mathrm{a} & 11.44 & \mathrm{bcd} & 10.74 & \mathrm{Bc} \\ \text { T4 Autumn } & 40.95 & 8.61 & \mathrm{ab} & 46.34 & \mathrm{bcd} & 0.42 & \mathrm{bc} & 9.80 & \mathrm{ab} & 5.58 & \mathrm{fgh} & 10.75 & \mathrm{Bc} \\ \text { T4 Summer } & 33.42 & 4.58 & \text { ef } & 51.95 & \mathrm{abc} & 0.69 & \mathrm{~b} & 11.08 & \mathrm{a} & 7.18 & \mathrm{defgh} & 8.02 & \mathrm{Bc} \\ \text { T5 Autumn } & 43.40 & 5.62 & \mathrm{cdef} & 37.30 & \mathrm{def} & 0.35 & \mathrm{bc} & 9.70 & \mathrm{ab} & 7.44 & \mathrm{cdefgh} & 7.40 & \mathrm{Cd}\end{array}$




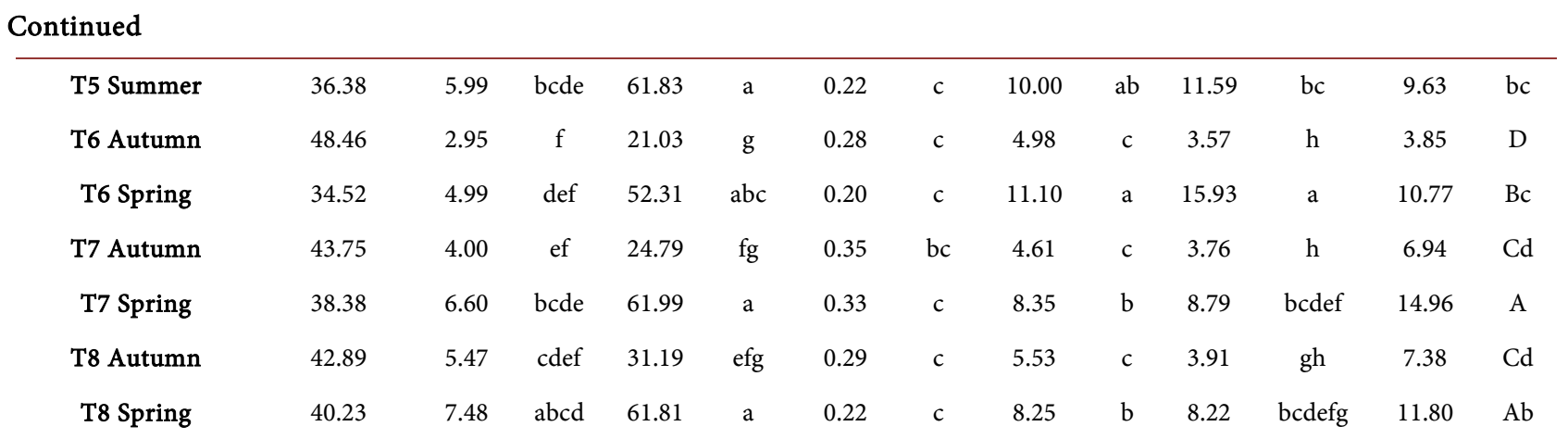

ns, ${ }^{*},{ }^{* *},{ }^{* *}$ Non-significant or significant at $\mathrm{P} \leq 0.05,0.01$, and 0.001 , respectively. Different letters within each column indicate significant differences according to Duncan's multiple-range test $(\mathrm{P}=0.05)$.

Considering the treatment as the source of variance, there was no significant difference among treatments for $\mathrm{N}$ and $\mathrm{Cl}$. However, for $\mathrm{PO}_{4}$ and $\mathrm{K}$, a significant difference, at $\mathrm{P} \leq 0.05$ was found among treatments with the highest levels of $\mathrm{PO}_{4}$ and $\mathrm{K}$ recorded for the treatments under fresh water, T1, T2, T3 and T4. Similarly, for $\mathrm{Ca}, \mathrm{Mg}$ and $\mathrm{Na}$, a significant difference, at $\mathrm{P} \leq 0.001$ was found among treatments with the highest levels recorded for the treatments under fresh water, T1, T2, T3 and T4.

Considering the season as the source of variance, there was a significant difference with the highest $\mathrm{N}$ and $\mathrm{PO}_{4}$ levels, $25 \%$ and $12 \%$ respectively, recorded for the autumn rather than the spring. The uptake of $\mathrm{K}, \mathrm{Mg}, \mathrm{Na}$ and $\mathrm{Cl}$ was significantly $49.09 \%, 30.20 \%, 96.79 \%$ and $33.20 \%$, respectively, higher in the summer than in autumn.

Vegetables contribute normally by $11 \%, 35 \%, 7 \%$, and $24 \%$ to the human dietary intake of total $\mathrm{P}, \mathrm{K}, \mathrm{Ca}$ and $\mathrm{Mg}$, respectively [27]. In the context of the current study, $\mathrm{K}$ was the predominant macronutrient present (Table 2). The results are in agreement with [15] who found that the highest $\mathrm{P}$ and $\mathrm{K}$ contents were recorded in rocket, spinach and green lettuce. Data on the mineral content of spinach have also been reported in the USDA database. Our results on mineral contents of spinach were proximate to those reported by the National Nutrient Database for Standard References (USDA). In addition, obtained results were below the Recommended Dietary Allowances (RDA) or Recommended Nutrient Intake of Spinach leaves for adults and children aged four years and older [28].

Differences with the mineral composition reported in the published literature could be attributed to different farming practices, environmental conditions and also cultivars. Importantly, the average contents of $\mathrm{N}$ and $\mathrm{PO} 4$ were significantly higher in autumn.

\subsection{Quality of Spinach Leaves}

The results of nitrate, lipohilic (LAA) and hydrophilic (HA) antioxidant activities and total phenol contents of spinach as related to the different water quality regimes, irrigation methods and growing seasons are given in Table 3. In general, nitrate levels in all treatments and seasons were below the maximum level in 
foodstuffs as provided by the European Comission regulations (No 1258/2011) of $2500-3500 \mathrm{mg} \cdot \mathrm{kg}^{-1}$ [29]. Obtained results present mean nitrate values higher than those given by [30] who found that spinach contains 24.0 - $457.0 \mathrm{mg}$ NO3. $\mathrm{kg}^{-1}$. However, according to the [31] and the results of two eminent surveys on leafy vegetables [32], [33], the concentration of nitrates in spinach ranged between 64 - $3048 \mathrm{mg} \cdot \mathrm{kg}^{-1}$ (fresh weight). Thus, the nitrate contents evaluated in this experiment were in the range reported by the former studies. Considering the treatment as the source of variance, there was a significant difference at $\mathrm{P} \leq$ 0.001 among treatments with the highest levels of nitrates recorded for the treatments $\mathrm{T} 1$ and $\mathrm{T} 2$ sprinkler irrigated with fresh water, followed by T3 and T4 that were drip irrigated with fresh water. The lowest nitrates levels were recorded for the treatments irrigated with treated wastewater independently of the irrigation method. Considering the season as the source of variance, there was a significant difference at $\mathrm{P} \leq 0.05$ with the highest nitrate levels recorded for the autumn rather than the spring.

For LAA, there was no significant difference among treatments and also among treatments and seasons interacting together. For ascorbic acid, treatments were significantly different at $\mathrm{P} \leq 0.05$ with the highest values recorded under sprinkler irrigation independently of water quality. The lowest values were recorded under drip irrigation. There was a significant difference at $\mathrm{P} \leq$ 0.001 with the highest HAA levels recorded for the autumn rather than the spring. [34] found vitamin $C$ concentration of spinach to be in the range of 25.0 - $71.0 \mathrm{mg} 100 \mathrm{~g}^{-1}$; however, [35] reported that spinach can contain up to 120.0 mg $100 \mathrm{~g}^{-1}$ vitamin $\mathrm{C}$ and also stated that vitamin $\mathrm{C}$ concentration increases during the winter season. Those results are in agreement with the findings of this experiment.

For the total phenols, there was significant difference among treatments at $\mathrm{P} \leq$ 0.001 . However, there was not a significant difference among seasons with $39.51 \%$ higher total phenol level recorded for the autumn rather than the spring.

\subsection{Bacterial Contamination of Spinach Leaves}

The bacterial contamination of the two studied spinach varieties grown under different water quality regimes, irrigation methods and growing seasons is provided in Table 4.

In general, pathogenic bacteria such as salmonella and Listeria monocytogenes were absent on spinach leaves for all treatments and growing seasons. In addition, Staphylococcus aureus and Clostridium perfringens were not detected. However, spinach leaves were mostly contaminated with microorganisms consisting of Enterobacteriacae particularly during the spring season while no contamination was recorded for the autumn season. The contamination by the Enterobacteriacae that was found on spinach leaves could not be attributed to the use of treated wastewater in T5, T6 and T7 because the same order of magnitude contamination was determined on the samples irrigated with fresh water in $\mathrm{T} 1$, 
Table 3. Analysis of variance and mean comparisons for nitrate, lipohilic (LAA) and hydrophilic (HA) antioxidant.

\begin{tabular}{ccccc}
\hline \multirow{2}{*}{ Source of variance } & NO3 & LAA & HAA & Total phenols \\
\cline { 2 - 5 } & $\left(\mathrm{mg} \cdot \mathrm{kg}^{-1}\right.$ f.wt. $)$ & $(\mathrm{mmol}$ Trolox/100g d.wt.) & (mmol Ascorbic acid/100g d.wt.) & (mg Gallic acid/100g d.wt.) \\
\hline Treatment (T) & $* * *$ & NS & $*$ & $* * *$ \\
Season (S) & $*$ & $* * *$ & $* *$ & NS
\end{tabular}

\section{Treatment}

$\begin{array}{llllllll}\text { T1 } & 1978.65 & \mathrm{a} & 7.51 & 2.30 & \mathrm{ab} & 68.15 & \mathrm{~A} \\ \text { T2 } & 1777.42 & \mathrm{ab} & 6.51 & 2.22 & \mathrm{bc} & 63.54 & \mathrm{~B} \\ \text { T3 } & 1021.53 & \mathrm{bc} & 6.72 & 2.13 & \mathrm{c} & 64.91 & \mathrm{Ab} \\ \text { T4 } & 866.53 & \mathrm{c} & 6.90 & 2.14 & \mathrm{bc} & 63.01 & \mathrm{Ab} \\ \text { T5 } & 938.12 & \mathrm{c} & 7.00 & 2.42 & \mathrm{a} & 57.62 & \mathrm{~B} \\ \text { T6 } & 737.36 & \mathrm{c} & 7.45 & 2.27 & \mathrm{bc} & 60.72 & \mathrm{~b} \\ \text { T7 } & 537.11 & \mathrm{c} & 7.61 & 2.04 & \mathrm{c} & 68.57 & \mathrm{a} \\ \text { T8 } & 626.07 & \mathrm{c} & 6.44 & 2.06 & \mathrm{c} & 62.62 & \mathrm{ab}\end{array}$

$\begin{array}{ccccc}\text { Season } & & & & \\ \text { Autumn } & 1251.67 & 7.81 & 2.58 & 74.89 \\ \text { Summer } & 878.13 & 6.35 & 1.88 & 53.68\end{array}$

$$
\mathrm{T} \times \mathrm{S}
$$

$\begin{array}{cccccc}\text { T1 Autumn } & 2891.62 & \mathrm{a} & 8.17 & 2.63 & 82.79 \\ \text { T1 Summer } & 1065.68 & \mathrm{~cd} & 6.85 & 1.98 & 53.51 \\ \text { T2 Autumn } & 2327.78 & \mathrm{ab} & 7.21 & 2.66 & 74.92 \\ \text { T2 Summer } & 1410.52 & \mathrm{bcd} & 5.80 & 1.79 & 52.16 \\ \text { T3 Autumn } & 1674.72 & \mathrm{bc} & 6.90 & 2.51 & 71.58 \\ \text { T3 Summer } & 586.07 & \mathrm{~d} & 6.53 & 1.75 & 58.23 \\ \text { T4 Autumn } & 880.58 & \mathrm{~cd} & 7.57 & 2.46 & 73.16 \\ \text { T4 Summer } & 852.47 & \mathrm{~cd} & 6.23 & 1.82 & 52.86 \\ \text { T5 Autumn } & 872.04 & \mathrm{~cd} & 8.46 & 2.68 & 67.38 \\ \text { T5 Summer } & 1004.19 & \mathrm{~cd} & 5.53 & 2.15 & 47.86 \\ \text { T6 Autumn } & 542.61 & \mathrm{~d} & 8.28 & 2.59 & 71.86 \\ \text { T6 Spring } & 867.19 & \mathrm{~cd} & 6.62 & 1.95 & 49.59 \\ \text { T7 Autumn } & 550.11 & \mathrm{~d} & 8.48 & 2.58 & 84.32 \\ \text { T7 Spring } & 524.11 & \mathrm{~d} & 7.02 & 1.68 & 58.07 \\ \text { T8 Autumn } & 537.30 & \mathrm{~d} & 7.18 & 2.50 & 78.93 \\ \text { T8 Spring } & 714.84 & \mathrm{~cd} & 6.20 & 1.91 & 57.18\end{array}$

ns, ${ }^{*},{ }^{* *},{ }^{* *}$ Non-significant or significant at $\mathrm{P} \leq 0.05,0.01$, and 0.001 , respectively. Different letters within each column indicate significant differences according to Duncan's multiple-range test $(\mathrm{P}=0.05)$. 
Table 4. Bacterial contamination of two spinach varieties grown under different water quality regimes, irrigation methods and growing seasons.

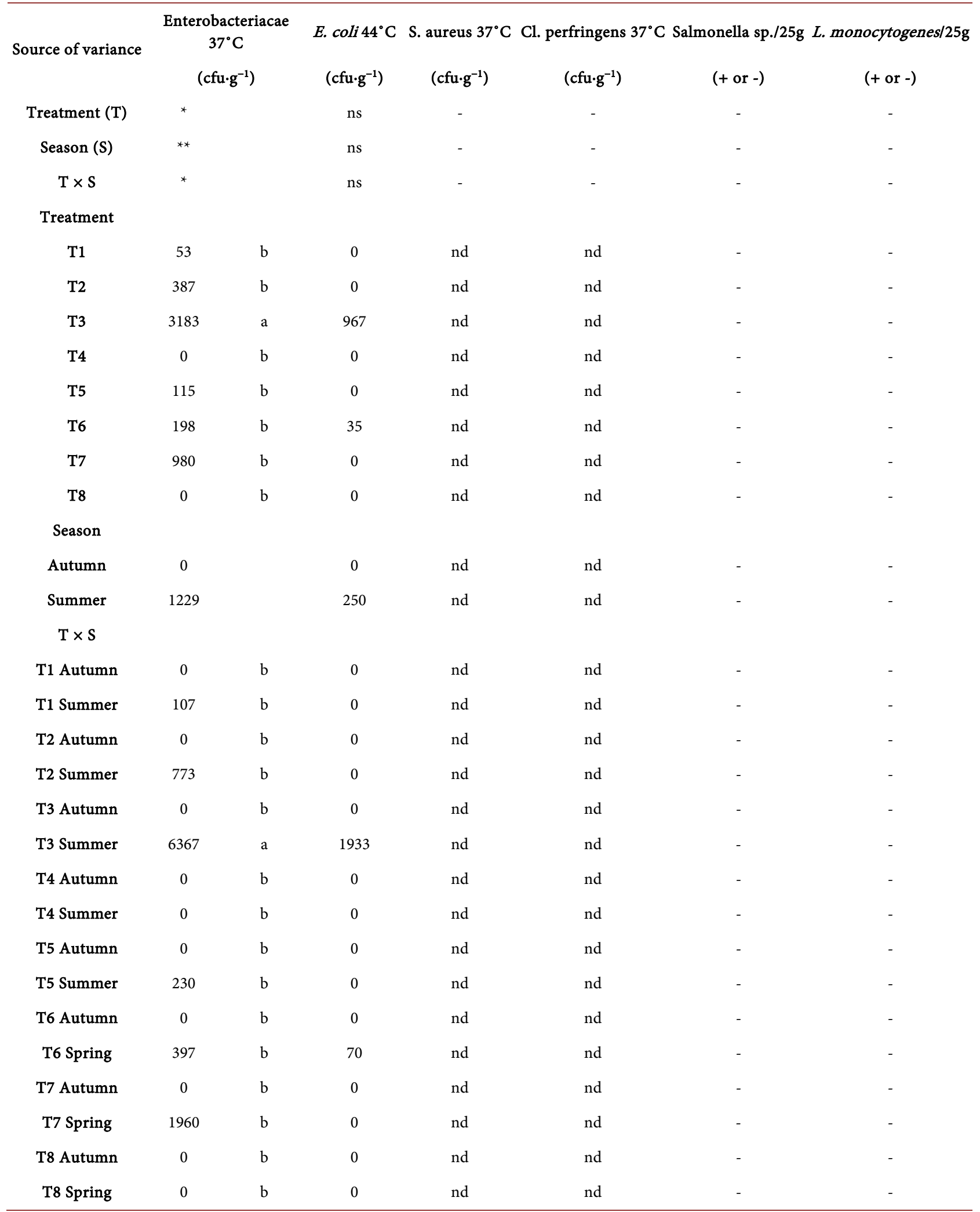

$\mathrm{ns},{ }^{*},{ }^{* *},{ }^{* *}$ Non-significant or significant at $\mathrm{P} \leq 0.05,0.01$, and 0.001 , respectively. Different letters within each column indicate significant differences according to Duncan's multiple-range test $(\mathrm{P}=0.05)$. nd, not detected. 
T2 and T3. In fact, the T3 treatment irrigated with fresh water was significantly different, with the highest value than all other treatments. E. coli was not detected in autumn season, however, it was only found on the T3 irrigated with fresh water and T6 irrigated with treated effluent in the spring season. The microbiological characteristics of the irrigation water could be only one of the routes for crop contamination. Another route for contamination could be probably boosted by favorable climatic conditions for bacterial development in the spring time rather than in the autumn time.

Similar results were obtained by [36] that studied the effect of wastewater irrigation on lettuce and found that bacterial contamination was present on treatments irrigated with treated water as well as on treatments irrigated with fresh water. Moreover, [37] highlighted that even though lettuce contamination by coliforms could be caused by water quality, the planting interval, harvest hygiene, and postharvest washing must also be taken into account. In addition, the crop handling, packaging, and transportation conditions are contamination routes. Finally, according to [38] low oxygen atmospheres could be used to store harvested spinach leaves and to control spoilage micro-organisms such as the Enterobacteriacae for at least 7 days, so long as the storage does not exceed $5^{\circ} \mathrm{C}$.

\section{Conclusions}

For the foregoing, it can be concluded that the treated waste water of Joubjnaine is not suitable for cultivation of vegetable crops and plants in terms of water quality but the approach of using treated waste water for raising crops is towards minimising cost of fertilizers and conservation of water resources. And the drip irrigation method in irrigated agriculture with treated waste water shall be adopted in order to reduce the direct contact between the plant and the water, and to limit the possible contamination of the crops products. However in terms of quantitative aspects, the findings results in this paper noted that the highest mean marketable yields recorded for the treatments that were used drip irrigated with treated waste water and there is no significant difference between the treatments in terms of qualitative aspects.

The knowledge on the reuse of treated waste water in irrigation is still scarce and more studies are needed to evaluate the quality of the treated effluent under different conditions and strict protection measures, stringent guidelines and good management of recycling of waste water are needed to minimize the negative impact of waste water irrigation in plants, soil and human health.

\section{Conflicts of Interest}

We certify that there are no affiliations with or involvement in any organization or entity with any financial interest and $i$ am not placed in a situation which could give rise to conflict of interests.

\section{References}

[1] Gatta, G., Libutti, A., Galiardi, A. and Beneduce, L. (2015) Treated Agro Industrial 
Waste Water Irrigation of Tomato Crop: Effects on Qualitative/Quantitative Characteristcs of Production and Microbiological Properties of the Soil; University of Foggia, Italy. Agriculture Water Management, 149, 33-43.

https://doi.org/10.1016/j.agwat.2014.10.016

[2] Al Ansari, N., Aldardor, W., Siergieiev, D. and Knutsson, S. (2013) Effect of Treated Wastewater Irrigation on Vegetables. Journal of Environmental Hydrology, V21, 1-12.

[3] Al Lahhan, A., El Assi, N.M. and Fayyad, M. (2003) Impact of Treated Waste Water Irrigation on Quality Attributes and Contamination of Tomato Fruit. Agricultural Water Management, 61, 51-62. https://doi.org/10.1016/S0378-3774(02)00173-7

[4] Geara, D., Moilleron, R., El Samarani, A., Lorgeoux, C. and Chebbo, G. (2010) State of Art about Water Use and Wastewater Management in Lebanon. Lebanese Science Journal, 11, 139-152.

[5] EMWATER (2004) Prospects of Efficient Wastewater Management and Water Reuse in Lebanon. Country Study Lebanon, Beirut, 77.

[6] Haruvy, N. (1997) Agricultural Reuse of Wastewater: Nation-Wide Cost Benefit Analysis. Culture. Ecosystems \& Environment, 66, 113-119.

https://doi.org/10.1016/S0167-8809(97)00046-7

[7] Oron, G., Campos C., Gillerman, L. and Salgo, M. (1999) Wastewater Treatment, Renovation and Reuse for Agricultural Irrigation in Small Communities. Agricultural Water Management, 38, 223-234. https://doi.org/10.1016/S0378-3774(98)00066-3

[8] Qadir, M.D., Wichelns, L., Rascid-Sally, P.G., McCornick, P., Drechsel, A. and Minhas, P.S. (2010) The Challenges of Wastewater Irrigation in Developing Countries. Agricultural Water Management, 97, 561-568. https://doi.org/10.1016/j.agwat.2008.11.004

[9] Qadir, M.D., Wichelns, L., Raschid-Sally, P.S., Minhas, P., Drechsel, A. and McCornick, P. (2007) Agricultural Use of Marginal-Quality Water-Opportunities and Challenges. In: Molden, D., Eds., Water for Food, Water for Life: A Comprehensive Assessment of Water Management in Agriculture, Earthscan, London.

[10] FAO/WHO (2011) Food Standards Programme. CODEX Alimentarius, Rome.

[11] MoA/FAO (2016) Agricultural Cencus. Ministry of Agriculture and Food and Agricultural Organization, Lebanon.

[12] APHA (1998) Standard Methods for the Examination of Water and Wastewater. 20th Edition, American Public Health Association, Washington DC.

[13] Giammanco, G., Pignato, S., Alliot, M. and Polgatti, M. (2002) Rapid Method for Salmonella Enumeration in Wastewater. Proceeding of the International Symposium on Salmonella and Salmonellosis, St. Brieuc, 29-31 May 2002, France.

[14] Bremner, J.M., Black, C.A., Evans, D.D., White, J.L., Ensminger, L.E. and Clark, F.E. (1965) Methods of Soil Analysis, Part 2 Chemical and Microbiological Properties, Agronomy Monographs 9. American Society of Agronomy, Soil Science Society of America, Madison, 1149-1178.

[15] Colonna, E., Rouphael, Y., Barbieri, G. and De Pascale, S. (2016) Nutritional Quality of Ten Leafy Vegetables Harvested at Two Light Intensities. Food Chemistry, 199, 702-710. https://doi.org/10.1016/j.foodchem.2015.12.068

[16] Fogliano, V., Verde, V., Randazzo, G. and Ritieni, A. (1999) Method for Measuring Antioxidant Activity and Its Application to Monitoring the Antioxidant Capacity of Wines. Journal of Agricultural and Food Chemistry, 47, 1035-1040. 
https://doi.org/10.1021/jf980496s

[17] Pellegrini, N., Yang, R.M. and Rice-Evans, C. (1999) Screening of Dietary Carotenoids and Carotenoid-Rich Fruit Extracts for Antioxidant Activities Applying 2,2'-azinobis (3-ethylenebenzothiazoline-6-sulfonic acid) Radical Cation Decolorization Assay. Methods in Enzymology, 299, 379-384. https://doi.org/10.1016/S0076-6879(99)99037-7

[18] Singleton, V.L., Orthofer, R. and Lamuela-Raventos, R.M. (1999) Analysis of Total Phenols and Other Oxidation Substrates and Antioxidants by Means of Folin-Ciocalteu Reagent. Methods in Enzymology, 299, 152-178. https://doi.org/10.1016/S0076-6879(99)99017-1

[19] MOE (2001) Decision Nb 8/1, Standards and Limits for Air Pollutants and Liquid Wastes Discharged by Classified Facilities and Waste Water Treatment Plants.

[20] FAO (2011) Effluent Specifications for Wastewater Reuse in Irrigation Based on Proposed Lebanese Guidelines.

[21] Solomon, E.B., Potenski, C.J. and Matthews, K.R. (2002) Effect of Irrigation Method on Transmission to and Persistence of E. coli O157:H7 on Lettuce. Journal of Food Protection, 65, 673-676. https://doi.org/10.4315/0362-028X-65.4.673

[22] Bernstein, N., Sela, S. and Neder-Lavon, S. (2007) Effect of Irrigation Regimes on Persistence Salmonella Enterica Serovar Newport in Small Experimental Pots Designed for Plant Cultivation. Irrigation Science, 26, 1-8. https://doi.org/10.1007/s00271-006-0059-3

[23] Citak, S. and Sonmez, S. (2010) Effects of Conventional and Organic Fertilization on Spinach (Spinacea oleracea L.) Growth Yield, Vitamin C and Nitrate Concentration during Two Successive Seasons. Scientia Horticulturae, 126, 415-420. https://doi.org/10.1016/j.scienta.2010.08.010

[24] Singh, P.K., Deshbhratar, P.B. and Ramteke, D.S. (2012) Effects of Sewage Wastewater Irrigation on Soil Properties, Crop Yield and Environment. Agricultural Water Management, 103, 100-104. https://doi.org/10.1016/j.agwat.2011.10.022

[25] Fonseca, A.F., Herpin, U., de Paula, A.M., Victória, R.L. and Melfi, A.J. (2007) Agricultural Use of Treated Sewage Effluents: Agronomic and Environmental Implications and Perspectives for Brazil. Scientia Agricola, 64, 194-209. https://doi.org/10.1590/S0103-90162007000200014

[26] Damasceno, L.M.O., Andrade, Jr.A.S., Gheyi, H.R., Ribeiro, V.Q. and Dias, N.S. (2010) Cultivation of Gerbera Irrigated with Treated Domestic Effluents. Revista Brasileira de Engenharia Agrícola e Ambiental, 14, 582-588. https://doi.org/10.1590/S1415-43662010000600003

[27] Levander, O.A. (1990) Fruit and Vegetable Contributions to Dietary Mineral Intake in Human Health and Disease. HortScience, 25, 1486-1488.

[28] Sahore, D.A. and Land Gbogouri, F. (2014) Assessment of Some Mineral Elements and Their Nutritional intake of Two Traditional Leafy Vgetables. International Journal and Research, 3.

[29] Commission Regulations (EU) No. 1258/2011. https://www.fsai.ie/uploadedFiles/Reg1258_2011.pdf

[30] Shokrzadeh, M., Shokravie, M., Ebadi, A.G., Babaee, Z. and Tarighati, A. (2007) The Measurement of Nitrate and Nitrite Content in Leek and Spinach Sampled from Central Cities of Mazandaran State of Iran. World Applied Sciences Journal, 2, 121-124. 
[31] EFSA (2008) Opinion of the Scientific Panel on Contaminants in the Food Chain on a Request from the European Commission to Perform a Scientific Risk Assessment on Nitrate in Vegetables. The EFSA Journal, 689, 1-79.

[32] Parks, S.E., Huett, D.O., Campbell, L.C. and Spohr, L.J. (2008) Nitrate and Nitrite in Australian Leafy Vegetables. Australian Journal of Agricultural Research, 59, 632-638. https://doi.org/10.1071/AR07198

[33] Santamaria, P., Elia, A., Serio, F. and Todaro, E.A. (1999) Survey of Nitrate and Oxalate Content in Retail Fresh Vegetables. Journal of the Science and Food and Agriculture, 79, 1882-1888.

https://doi.org/10.1002/(SICI)1097-0010(199910)79:13<1882::AID-JSFA450>3.0.CO ;2-D

[34] Bergquist, A.M., Gertsson, U.E., Nordmark, Y.G. and Olsson, M.E. (2007) Ascorbic Acid Carotenoids, and Visual Quality of Baby Spinach as Affected by Shade Netting and Postharvest Storage, Journal of Agricultural and Food Chemistry, 55, 8444-8451. https://doi.org/10.1021/jf070396z

[35] Fujiwara, T., Kumakura, H., Ohta, S., Yoshida, Y. and Kameno, T. (2005) Seasonal Variation of 1-Ascorbic Acid and Nitrate Content of Commercially Available Spinach. Horticulture Research, 4, 347-352. https://doi.org/10.2503/hrj.4.347

[36] Urbano, V.R., Mendonca, T.G., Bastos, R.G. and Souza, C.F. (2017) Effects of Treated Wastewater Irrigation on Soil Properties and Lettuce Yield. Agricultural Water Management, 181, 108-115. https://doi.org/10.1016/j.agwat.2016.12.001

[37] Santos, Y.O., Almeida, R.C., Guimarães, A.G. and Almeida, P.F. (2010) Hygienic-Sanitary Quality of Vegetables and Evaluation of Treatments for the Elimination of Indigenous E. coli and E. coli O157:H7 from the Surface of Leaves of Lettuce (Lactuca sativa L.). Food Science and Technology, 30, 1083-1089. https://doi.org/10.1590/S0101-20612010000400038

[38] Babic, I. and Watada, A.E. (1996) Microbial Populations of Fresh-Cut Spinach Leaves Affected by Controlled Atmospheres. Postharvest Biology and Technology, 9, 87-89. https://doi.org/10.1016/S0925-5214(96)00047-6 